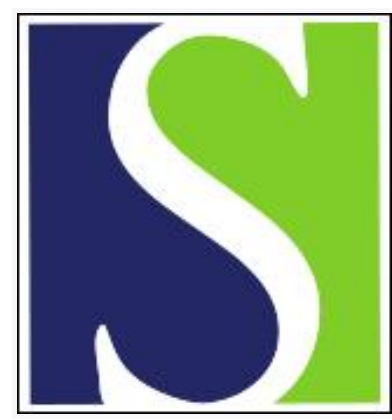

Scand J Work Environ Health 1990;16(6):411-422

https://doi.org/10.5271/sjweh.1768

Issue date: 01 Dec 1990

Combined effect of silica dust exposure and tobacco smoking on the prevalence of respiratory impairments among gold miners.

by Hnizdo E, Baskind E, Sluis-Cremer GK

Affiliation: Epidemiology Research Unit, Medical Bureau for Occupational Diseases, Johannesburg, South Africa.

This article in PubMed: www.ncbi.nlm.nih.gov/pubmed/2178280

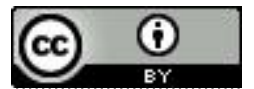




\title{
Combined effect of silica dust exposure and tobacco smoking on the prevalence of respiratory impairments among gold miners
}

\author{
by Eva Hnizdo, MSc, Eugene Baskind, MD, Gerhard K Sluis-Cremer, MD1
}

\begin{abstract}
HNIZDO E, BASKIND E, SLUIS-CREMER GK. Combined effect of silica dust exposure and tobacco smoking on the prevalence of respiratory impairments among gold miners. Scand $J$ Work Environ Health 1990;16:411-22. The combined effect of underground gold mining dust with a high content of free silica and tobacco smoking on the prevalence of respiratory impairment was examined among 2209 South African gold miners and 483 nonminers. The subjects were grouped as having normal function; minimal, moderate or marked obstruction; marked obstruction with restriction; or pure restriction on the basis of their lung function profiles. Each profile group was compared with the normal group for exposure prevalences, and additive and multiplicative relative risk models were applied to test for departure from the additivity of individual effects. Departure from additivity was found to increase progressively with the severity of obstructive impairment. The results indicated that approximately $94 \%$ of the cases with the most severe respiratory impairment $(\mathrm{N}=191)$ could have been prevented through the elimination of tobacco smoking. In conclusion, tobacco smoking was found to potentiate the effect of dust on respiratory impairments.
\end{abstract}

Key terms: interaction, pattern of respiratory impairment, silica dust, smoking, underground miners.

South African gold miners are exposed to dust with a high content of crystalline silica. About $60 \%$ of the virgin rock is silica, and approximately $30 \%$ of the respirable dust is free silica (1). The average current levels of respirable silica representative of the gold mining industry ranges from 0.05 to $0.84 \mathrm{mg} / \mathrm{m}^{3}$ for underground air (1). In addition, tobacco smoking is highly prevalent among the white miners. About $70 \%$ were found to be current smokers, and only $12 \%$ were nonsmokers $(2,3)$.

Occupational exposure to underground dust in South African gold mines has been found to be associated with an increased prevalence of respiratory symptoms $(2,3)$, chronic obstructive lung disease (3), and emphysema identified at autopsy (4, unpublished paper "Emphysema Type in Relation to Silica Dust Exposure, in South African Gold Miners" by Hnizdo et al). Experimental evidence from rats also indicates that exposure to crystalline silica causes emphysema and abnormally thick walls in the small airways with associated functional changes of airflow obstruction in rats $(5,6)$.

There is, however, little evidence in the literature to indicate whether tobacco smoking interacts with silica dust to increase the amount of respiratory dysfunction (7). The objective of this study was to examine the effect of combined exposure to silica dust and tobacco smoking on the prevalence of respiratory dysfunction. It has been pointed out that, in the assess-

\footnotetext{
Epidemiology Research Unit, Medical Bureau for Occupational Diseases, Johannesburg, South Africa.
}

Reprint requests to: Ms E Hnizdo, Epidemiology Research Unit, Medical Bureau for Occupational Diseases, PO Box 4584, Johannesburg 2000, South Africa. ment of the combined effect of tobacco smoking and occupational exposure, the pattern of lung injury in pulmonary function, rather than a single lung function measure, should be examined $(8,9)$. Thus, in this study, both, the individual lung function measures [forced expiratory volume in $1 \mathrm{~s}\left(\mathrm{FEV}_{1.0}\right)$, vital capacity (VC), and forced midexpiratory flow $\left.\left(\mathrm{FEF}_{25-75}\right)\right]$ and the spirogram pattern were analyzed.

We reanalyzed the data from a study (3) of 2209 white South African gold miners and 483 nonminers to (i) examine the individual lung function measurements $\mathrm{FEV}_{1.0}, \mathrm{VC}$, and $\mathrm{FEF}_{25-75}$ for any dose-response trend and for the presence of interaction between dust and smoking; (ii) examine the patterns and degree of ventilatory impairment as reflected in the spirogram, their relation to silica dust and tobacco smoking, and the presence of interaction; (iii) estimate the attributable risk for tobacco smoking and underground gold mining dust exposure; (iv) examine the relevance of the pattern of ventilatory impairment to mortality from respiratory and cardiovascular diseases.

\section{Subjects and methods}

\section{Study subjects}

The 2209 study subjects consisted of all white gold miners who fulfilled the following criteria: (i) a number from the Medical Bureau for Occupational Diseases within the range of $\mathrm{B} 9000$ to $\mathrm{C} 8999$; (ii) age 45-54 years; (iii) minimal underground service of 10 years; (iv) residence in South Africa for at least 20 years; (v) service in mines other than gold less than two years; and (vi) attendance for a medical examination at the Medical Bureau for Occupational Diseases 
during the four-year period between 1968 and 1971 . An annual medical examination is compulsory for all miners working in dusty occupations. Miners who were retired but attended the medical examination because they were seeking compensation or a medical examination were also included in the selection procedure. Only one of the medical examinations which the miners attended during the study period was used for the purposes of the study. A group of 483 male nonminers of the same age group, drawn at random from various municipal and government departments through the inclusion of all the workers from a particular office, was included in the original study of Wiles \& Faure as a reference group but was not reported on in their paper (3). They were included in this reanalysis of the data.

\section{Mining exposure}

The mining service was estimated from records of the Chamber of Mines. These records show the exact number of shifts worked in each occupation. The occupations were classified on the basis of dust counts done by Beadle (10) into 11 groups for which the average surface area of respirable dust particles $(<5 \mu \mathrm{m})$, after heat and acid treatment that leaves mainly silica particles, was calculated. For each miner the number of shifts worked in each occupation was weighted by the mean respirable dust count for that occupational group. The dust exposure was analyzed in terms of particle-years cumulated to the date of the medical examination (GOLDPY), and categorized particleyears $/ 10000(0,1-1.5,1.6-2.5,2.6-3.5,3.6-4.5$, $\geq 4.6$ ) (GOLDPYC), for which the means of the ranges were used to estimate the dose-response relationship. In a preliminary analysis particle-years were more strongly associated with the spirogram measurements than years of exposure.

\section{Smoking habits}

Full details of the smoking habits were obtained by means of a smoking questionnaire, and the reliability of the answers was checked against smoking histories recorded in the medical files of the Medical Bureau for Occupational Diseases. The information on smoking habits was utilized in the analysis in three different ways. First, the subjects were grouped into nonsmokers, ex-smokers, and current smokers, and indicator (zero, one) variables SMK1 (ex-smoker) and SMK2 (current smoker) were created to represent the grouping. Second, the tobacco consumption and smoking status were combined, and the subjects were divided into the following five categories: $0=$ nonsmoker, $1=$ ex-smoker, $3=$ current smoker with $<20$ pack-years, $4=$ current smoker with $20-39$ packyears, and $5=$ current smoker with $\geq 40$ pack-years (SMOKEC). Third, lifetime tobacco consumption was analyzed as cigarette equivalent pack-years (SMOKEPY).

\section{Lung function tests}

The spirograms were measured on a Godard watersealed spirometer with the subject seated and wearing a nose clip. Spirograms judged to be of poor technical quality were excluded by a pulmonary physiologist. The lung function parameters measured were VC, $\mathrm{FEV}_{1.0}$, and $\mathrm{FEF}_{25-75}$.

For the analysis of the pattern of ventilatory impairments the miners were grouped according to the presence of an obstructive or restrictive lung function profile, and those with the obstructive profile were further subdivided according to the degree of obstruction.

A method of categorization used for asbestos-exposed workers (9) was adapted through the incorporation of features that are used by the Pulmonary Unit of Medical Bureau for Occupational Diseases when the types of lung dysfunction are categorized. The observed lung function tests were considered low if they fell below a 95 or $99 \%$ confidence limit. The confidence limits were calculated as (predicted value $-\mathrm{SEE} \cdot \mathrm{z}$ ), where the predicted value was calculated from the equations given later in the report, SEE was the standard error of the estimate, and $z=1.645$ or 2.326 for the 95 and $99 \%$ confidence limit, respectively. The lung function tests were considered normal if they were above the lower $95 \%$ confidence limit.

The prediction equations were derived by the Lung Function Unit of the Medical Bureau for Occupational Diseases and are routinely used for the assessment of lung function impairment in white miners who come to the Bureau for their medical examination. The equations were derived from 731 healthy miners consisting of $34 \%$ smokers, $41 \%$ ex-smokers, and $25 \%$ nonsmokers who came to the Bureau during 1984. They averaged 51 years in age, $174.5 \mathrm{~cm}$ in height, and 81 $\mathrm{kg}$ in weight. The $95 \%$ confidence limits estimated from Crapo's prediction equations [derived from a nonsmoking, white male population (11)] and from equations of the Medical Bureau for Occupational Diseases are very comparable for the ages considered in this study ( $45-54$ years). The lower $95 \%$ condifence limits derived from Crapo's equations and those of the Medical Bureau for Occupational Diseases for a man 51 years of age, $174 \mathrm{~cm}$ tall, and weighing $81 \mathrm{~kg}$ are 3.64 and 3.76 for $\mathrm{VC}, 2.97$ and 2.97 for $\mathrm{FEV}_{1.0}$, 2.08 and 2.32 for $\mathrm{FEF}_{25-75}$, and 71.85 and 70.51 for $\mathrm{FEV}_{1.0} / \mathrm{VC}$, respectively. The main difference in the two sets of predictive curves was the weight factor included in the equations of the Medical Bureau for Occupational Diseases. Weight was found to be a significant negative predictor for lung function among white South African gold miners, who are often overweight. The midexpiratory flow time (MEFT) was calculated as $\mathrm{VC} /\left(2 \cdot \mathrm{FEF}_{25-75}\right)$.

The prediction equations and standard errors of the estimate (SEE) were as follows:

\footnotetext{
$\mathrm{VC}=-5.57964-0.02195(\mathrm{AGE})+0.06822(\mathrm{HEIGHT})$ -0.00777 (WEIGHT)
} 


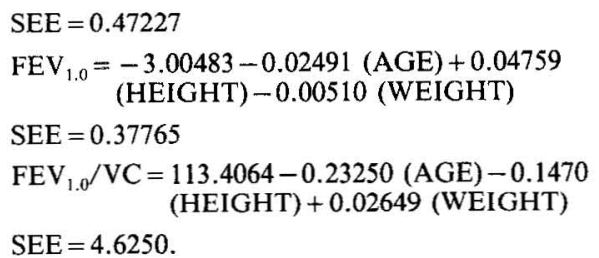

The subjects were grouped into six categories according to the lung function profile as follows: (i) normal (reference category) [those with normal lung function tests (ie, normal VC, $\mathrm{FEV}_{1.0}, \mathrm{FEV}_{1.0} / \mathrm{VC}$, and MEFT $\geq 1 \mathrm{~s}$ )]; (ii) minimal obstruction (those who had a normal VC and one or two features of obstruction, but not all three, present, the three features being low $\mathrm{FEV}_{1.0}$, low $\mathrm{FEV}_{1.0} / \mathrm{VC}$, and MEFT $>1 \mathrm{~s}$ ); (iii) moderate pure obstruction (those with a normal VC, an $\mathrm{FEV}_{1.0}$ between the 95 and $99 \%$ lower confidence limits, a low $\mathrm{FEV}_{1.0} / \mathrm{VC}$, and an MEFT of $>1 \mathrm{~s}$ ); (iv) marked pure obstruction (those with a normal VC, an $\mathrm{FEV}_{1.0}$ below the $99 \%$ confidence limit, a low $\mathrm{FEV}_{1.0} / \mathrm{VC}$, and an MEFT of $>1 \mathrm{~s}$ ); (v) marked obstruction with restriction (those with marked pure obstruction except that the VC was below the $99 \%$ confidence limit) (all the subjects with an obstructive and a restrictive element were found to have an $\mathrm{FEV}_{1.0}$ value that was below the $99 \%$ confidence limit); and (vi) pure restriction (those with a low VC, a normal $\mathrm{FEV}_{1.0}$, a normal $\mathrm{FEV}_{1.0} / \mathrm{VC}$ ratio, and an MEFT of $\leq 1 \mathrm{~s}$ ). Four men were found to have restrictive impairment with a minimal obstructive element, and they were combined with the pure restrictive group.

There were 202 men whose lung function tests were excluded from the original study by a pulmonary physiologist, as they were considered to be submaximal efforts, and the lung functions were not recorded in the computer file. In addition, the lung function tests of 21 men were rejected from the analysis on the advice of one of the authors (EB), as they were found to have very unusual parameters and did not belong to any of the aforementioned categories.

\section{Other medical and compensation data}

The medical examination included the assessment of (i) simple chronic bronchitis by a questionnaire, (ii) rhonchi, (iii) sputum production, and (iv) radiological silicosis (3).

The medical files of the Medical Bureau for Occupational Diseases record dates and types of compensation awarded to miners. Compensation for pneumoconiosis or chronic obstructive lung disease can be awarded if radiological silicosis or specified lung dysfunction is found and the person has worked at least 10 years in highly dusty occupations or 20 years in less dusty occupations.

\section{Mortality data}

The follow-up period for the collection of mortality data was from the date of the examination to the end of 1987 , by which time 859 of the 2209 miners whose lung functions were measured had died. The deaths were identified through a miners' pension fund and the Department of Interior. The causes of death were coded according to the ninth revision of the International Classification of Diseases (ICD) of the World Health Organization by an independent physician, using the best available information derived from the death certificate, autopsy report, and medical file of the Medical Bureau for Occupational Diseases. The causes of death of interest to this analysis are chronic obstructive lung disease (ICD 416, 491, 492 and 496) and ischemic heart disease (ICD 410-414).

\section{Statistical methods}

Analysis of lung function measurements. First, the relationship between each lung function measurement $\left(\mathrm{FEV}_{1.0}, \mathrm{VC}\right.$ and $\mathrm{FEF}_{25-75}$ ), and dust and smoking was evaluated by means of a linear regression analysis in which the effect of age, body weight, and height were adjusted for. Second, the individual measurements were dichotomized into normal and abnormal if they fell above or below the 95 (or 99) $\%$ confidence limit of the predicted value, and the general relative risk model (12) was applied to assess the presence of interaction.

Analysis of the lung function profiles. For the analysis of the lung function profiles, the cases in each of the five impaired profiles were compared with the reference category for differences in exposure prevalences by means of the exposure odds ratio. The following tests were applied: (i) a test for interaction and (ii) the estimation of attributable risk. In the test for interaction the null hypothesis of the absence of an interaction effect was postulated in terms of the additivity of relative risks $(13-15)$. In the test for the null hypothesis several types of exposure variables were employed. The dose-response trends in the odds ratios for each impairment and the individual dust levels were compared between the nonsmokers, ex-smokers, and current smokers. The indicator smoking variables, SMK1 and SMK2, were employed to test whether the ex-smokers and current smokers differed from the nonsmokers in their dose-response trend for the categorized dust variable GOLDPYC. The fully saturated additive relative risk model was of the form:

$$
\begin{aligned}
\log [\mathrm{P} /(1-\mathrm{P})]= & \alpha+\log \left\{1+\beta_{1} \cdot(\mathrm{GOLDPYC})+\beta_{2}\right. \\
& \cdot(\mathrm{SMK} 1)+\beta_{3}(\mathrm{SMK} 2)+\beta_{4} \cdot(\mathrm{SMK} 1 \\
& \cdot \text { GOLDPYC })+\beta_{5} \cdot(\mathrm{SMK} 2 \\
& \cdot \text { GOLDPYC }),
\end{aligned}
$$

where $\mathrm{P}$ was the probability of being a case, $\alpha$ was a nuisance parameter; $\{\cdot\}$ estimated the odds ratio for 
the exposed subjects relative to the subjects whose exposure was zero; the $\beta$ coefficients estimated the excess relative risk due to each effect, coefficients $\beta_{2}$ and $\beta_{3}$ measuring the change in the intercept value caused by the ex-smoker and current smoker effect and $\beta_{4}$ and $\beta_{5}$ measuring the rate of change in the odds ratios with increasing dust level for ex-smokers and current smokers, respectively. The coefficients $\beta_{4}$ and $\beta_{5}$ indicated whether tobacco smoking modified the effect of mining dust exposure. The likelihood ratio test for testing the null hypothesis of no interaction (ie, $\mathrm{H}_{0}: \beta_{4}=\beta_{5}=0$ against $\mathrm{H}_{2}: \beta_{4}$ and/or $\beta_{5} \neq 0$ ) was given by $\mathrm{X}_{\mathrm{LR}}{ }^{2}=-2 \log \left(\hat{\mathrm{L}}_{1} / \hat{\mathrm{L}}_{2}\right)$, where $\log \hat{\mathrm{L}}_{1}$ and $\log \hat{\mathrm{L}}_{2}$ were the maximized $\log$ likelihoods estimated from the model without interaction and with interaction, respectively. The multiplicative model (ie, the logistic model) with the same variables was also fitted to the data.

A test of interaction using either both categorized or both continuous exposure variables was also performed. The additive relative risk function was applied as

$$
\begin{aligned}
\operatorname{RR}\left(x_{1}, x_{2} ; \beta\right)= & 1+\beta_{0}+\beta_{1} \cdot x_{1} \\
& +\beta_{2} \cdot x_{2}+\beta_{3} \cdot x_{1} \cdot x_{2},
\end{aligned}
$$

equation 2

where $x_{1}$ represented the dust variable (GOLDPYC or GOLDPY) and $x_{2}$ the smoking variable (SMOKEC or

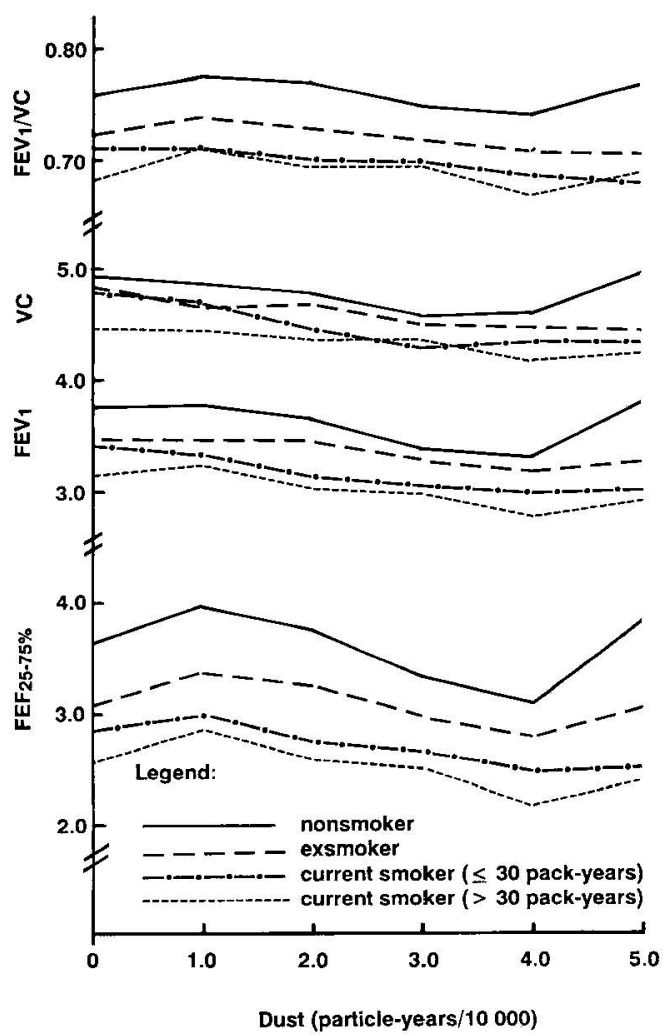

Figure 1. Individual lung function measurements, plotted against dust particle-years, according to smoking habits. $\left(\mathrm{FEF}_{25-75} \%=\right.$ forced midexpiratory flow, $\mathrm{FEV}_{1}=$ forced expiratory volume in $1 \mathrm{~s}, \mathrm{VC}=$ vital capacity)
SMOKEPY). The likelihood ratio test for testing the null hypothesis of no interaction (ie, $\mathrm{H}_{0}: \beta_{3}=0$ against $\left.\mathrm{H}_{\mathrm{a}}: \beta_{3} \neq 0\right)$ was given by $\mathrm{X}_{\mathrm{LR}}{ }^{2}=-2 \log \left(\hat{\mathrm{L}}_{1} / \hat{\mathrm{L}}_{2}\right)$ as in the preceding test.

The computer program RISK (16) was used to fit the relative risk (equation 2 ), and the computer program MINUIT (17) was used to fit equation 1. The program MINUIT is a general minimization program and was used to fit the maximum likelihood function for grouped data, and, where zero values occurred, a value of 0.5 was added to each cell. For comparison SAS PROC CATMOD (18) was also applied to fit the additive and multiplicative models with grouped likelihood function to the data in table 4 in the Results section; the option ADDCELL $=0.5$ was used to replace zero cell values. The results obtained were comparable with those from MINUIT. The results obtained from the programs RISK and MINUIT were almost identical for the continuous and categorized variables.

In the estimation of attributable risk the method of calculation, as proposed by Miettinen (19) and Bruzzi et al (20), and applied by Kjuus et al (21) to the calculation of attributable risk for smoking and occupational exposure for lung cancer, was applied. The etiologic fraction for dust $\left(E F_{d}\right)$ was estimated as:

$$
\mathrm{EF}_{\mathrm{d}}=\sum_{\mathrm{i}=1}^{\mathrm{k}} \mathrm{p}_{\mathrm{ci}} \cdot\left[\left(\mathrm{OR}_{\mathrm{i}}-1\right) / \mathrm{OR}_{\mathrm{i}}\right] \text {, }
$$

equation 3

where $\mathrm{p}_{\mathrm{ci}}$ was the estimated proportion of cases in the ith exposure category $(\mathrm{i}=1,2, \ldots, \mathrm{k}), \mathrm{OR}_{\mathrm{i}}>1$, and $\mathrm{OR}_{\mathrm{i}}$ were the odds ratios estimated by logistic regression in which the effect of age and smoking were adjusted. The etiologic fractions for smoking $\left(\mathrm{EF}_{\mathrm{s}}\right)$ and for the combined effect of dust and smoking $\left(\mathrm{EF}_{\mathrm{d} . \mathrm{s}}\right)$ were estimated in the same manner. The $95 \%$ confidence limits for the summary etiologic fractions were estimated as in Denman \& Schlesselman (22). With the use of the etiologic fractions, the proportion of cases that could be prevented by the elimination of each of the factors (PF) was calculated as follows: $\mathrm{PF}_{\text {dust }}=$ $\mathrm{EF}_{\mathrm{d} \cdot \mathrm{s}}-\mathrm{EF}_{\mathrm{s}}, \mathrm{PF}_{\mathrm{smoking}}=\mathrm{EF}_{\mathrm{d} \cdot \mathrm{s}}-\mathrm{EF}_{\mathrm{d}}, \mathrm{PF}_{\text {dust } \cdot \text { smoking }}=$ $\mathrm{EF}_{\mathrm{d} \cdot \mathrm{s}}-\mathrm{EF}_{\mathrm{d}}-\mathrm{EF}_{\mathrm{s}}, \mathrm{PF}_{\text {other }}=1.00-\mathrm{EF}_{\mathrm{d} \cdot \mathrm{s}}$.

\section{Results}

\section{Lung function tests}

Figure 1 shows the mean values for the $\mathrm{FEV}_{1.0}, \mathrm{VC}$, $\mathrm{FEF}_{25-75}$, and $\mathrm{FEV}_{1.0} / \mathrm{VC}$ measurements plotted according to categorized dust particle-years for the nonsmokers, ex-smokers, current smokers of $\leq 30$ packyears, and current smokers of $>30$ pack-years. The graphs display an interesting pattern. For $\mathrm{FEF}_{25-75}$ the values for the nonminers (DUST $=0$ ) are lower than those for the miners in the lowest exposure category $($ DUST $=1)$. For all four variables there is a declining slope for the miners up to the dust level of 40000 particle-years. If one considers the data up to that point, it can be observed that the decrease that 
occurs as the dust exposure increases is approximately parallel for all the smoking categories and that there is no indication that dust and smoking interact to increase the impairment. The consistent increase in the lung function measurements in the highest dust exposure category is presumably due to some systematic effect, possibly a healthy worker effect. The rate of decrease associated with increasing dust level in the region up to 40000 particle-years is highest for $\mathrm{FEF}_{25-75}$ and lowest for $\mathrm{VC}$, but the changes in $\mathrm{FEV}_{1.0}$ and $\mathrm{VC}$ are almost parallel.

The results from the linear regression analysis done for the lung function tests confirmed the aforementioned observation, namely, that the interaction effect between dust and smoking is not statistically significant. The regression coefficients for dust particleyears $/ 1000$ adjusted for the effect of age, height, weight, and smoking (pack-years) were -0.0067 (SE 0.0013 ), -0.0052 (SE 0.0012) and -0.0118 (SE $0.0022)$ for $\mathrm{FEV}_{1.0}, \mathrm{VC}$, and $\mathrm{FEF}_{25-75}(\mathrm{P}<0.0001)$, respectively. For the dichotomized $\mathrm{FEV}_{1.0}$ and VC variables (normal versus lower than the 95 or $99 \%$ confidence limit) the interaction effect was also not significant when tested by the additive model, even when the subjects with both measurements, $\mathrm{FEV}_{1.0}$ and $\mathrm{VC}$, lower than the $99 \%$ confidence limit were compared with the rest of the subjects.

\section{Lung function profiles}

Tables $1-3$ show the distribution of the miners into the six lung function profile groups and their characteristics. The groups did not differ in age, but the two groups with restriction were slightly taller and those with the restrictive profile were considerably heavier in comparison with the other groups. Tobacco consumption displayed an increasing trend with obstruction. The lung function values decreased, and the proportions of those having bronchitis and rhonchi increased as the level of obstruction increased. The dust particle-years increased up to moderate obstruction only and then declined slightly. This pattern is reflected by the proportion of men with silicosis. The proportions of those who came for a benefit examination (because they were seeking compensation) and of those already certified also increased with the level of obstruction. The mortality from respiratory diseases showed a strong association with increasing obstruction. The restrictive profile group had the highest percentage of death from ischemic heart disease.

Test for interaction. Table 4 shows the distribution of the subjects in the six lung function profile groups according to smoking habits and dust exposure. In a comparison with the reference group, the observed odds ratios indicated an increase in the prevalence of each impairment as the dust and smoking exposure increased. There was some difficulty in selecting the baseline groups for the calculation of the odds ratios. As the nonminers (DUST $=0$ ) had higher proportions of obstructive impairments in all three smoking categories than the miners with the lowest dust exposure (DUST $=1$ ), they were excluded from further analyses, and the values of the miners with the lowest dust exposure (DUST $=1$ ) were used as the base line. The value of 0.5 was added to the cell frequencies for computational reasons; this procedure had the effect of increasing the prevalences among the nonsmokers, but it did not increase the dose-response trend among the

Table 1. Physical characteristics and cigarette consumption of the lung function groups, miners only.

\begin{tabular}{|c|c|c|c|c|c|c|c|c|c|c|c|c|}
\hline \multirow{3}{*}{$\begin{array}{l}\text { Lung } \\
\text { function } \\
\text { profile } \\
\text { group }\end{array}$} & \multirow{2}{*}{\multicolumn{2}{|c|}{$\begin{array}{c}\text { Age } \\
\text { (years) }\end{array}$}} & \multirow{2}{*}{\multicolumn{2}{|c|}{$\begin{array}{l}\text { Weight } \\
(\mathrm{kg})\end{array}$}} & \multirow{2}{*}{\multicolumn{2}{|c|}{$\begin{array}{l}\text { Height } \\
(\mathrm{cm})\end{array}$}} & \multirow{2}{*}{\multicolumn{2}{|c|}{$\begin{array}{c}\text { Body mass } \\
\text { index } \\
{\left[\left(\mathrm{kg} / \mathrm{m}^{3}\right) \times 100\right]}\end{array}$}} & \multicolumn{4}{|c|}{$\begin{array}{l}\text { Cigarette-equivalent } \\
\text { consumption }\end{array}$} \\
\hline & & & & & & & & & \multicolumn{2}{|c|}{ Pack-years } & \multicolumn{2}{|c|}{ Years } \\
\hline & Mean & SD & Mean & SD & Mean & SD & Mean & SD & Mean & $S D$ & Mean & $\mathrm{SD}$ \\
\hline $\begin{array}{l}\text { Normal } \\
\text { (reference } \\
\text { group) } \\
(N=1030)\end{array}$ & 50.1 & 2.6 & 82.5 & 12.0 & 175.4 & 6.1 & 26.8 & 3.3 & 21.2 & 17.3 & 19.2 & 12.1 \\
\hline $\begin{array}{l}\text { Minimal } \\
\text { obstruction } \\
(N=256)\end{array}$ & 50.0 & 2.5 & 80.3 & 11.5 & 174.9 & 6.1 & 26.2 & 3.2 & 24.7 & 16.9 & 22.5 & 10.7 \\
\hline $\begin{array}{l}\text { Moderate } \\
\text { obstruction } \\
(\mathrm{N}=111)\end{array}$ & 50.6 & 2.4 & 78.8 & 12.0 & 174.7 & 6.6 & 25.8 & 3.4 & 27.5 & 14.8 & 25.3 & 8.4 \\
\hline $\begin{array}{l}\text { Marked } \\
\text { obstruction } \\
(\mathrm{N}=211)\end{array}$ & 50.3 & 2.5 & 78.1 & 12.3 & 174.8 & 5.6 & 25.5 & 3.6 & 29.4 & 17.1 & 26.1 & 9.4 \\
\hline $\begin{array}{l}\text { Marked } \\
\text { obstruction } \\
\text { with restriction } \\
(\mathrm{N}=191)\end{array}$ & 50.5 & 2.5 & 79.3 & 12.2 & 176.2 & 5.3 & 25.5 & 3.5 & 31.4 & 16.6 & 27.0 & 7.6 \\
\hline $\begin{array}{l}\text { Restriction } \\
(\mathrm{N}=187)\end{array}$ & 50.4 & 2.6 & 85.0 & 12.9 & 176.9 & 5.8 & 27.1 & 3.8 & 26.3 & 16.8 & 23.2 & 10.1 \\
\hline
\end{tabular}


Table 2. Lung function values of the lung function profile groups and the percentage of the groups with bronchitis, sputum, and rhonchi, miners only. $\left(F E V_{1.0}=\right.$ forced expiratory volume in $1 \mathrm{~s}, F E F_{25-75}=$ forced midexpiratory flow, VC $=$ vital capacity)

\begin{tabular}{|c|c|c|c|c|c|c|c|c|c|}
\hline \multirow{2}{*}{$\begin{array}{l}\text { Lung function } \\
\text { profile group }\end{array}$} & \multicolumn{2}{|c|}{ FEV $_{1.0}$} & \multicolumn{2}{|c|}{$\mathrm{FEF}_{25-75}$} & \multicolumn{2}{|c|}{ VC } & \multirow{2}{*}{$\begin{array}{l}\text { Bronchitis } \\
(\%)\end{array}$} & \multirow{2}{*}{$\begin{array}{l}\text { Sputum } \\
(\%)\end{array}$} & \multirow{2}{*}{$\begin{array}{l}\text { Rhonchi } \\
(\%)\end{array}$} \\
\hline & Mean & SD & Mean & SD & Mean & $S D$ & & & \\
\hline $\begin{array}{l}\text { Normal (reference } \\
\text { group) } \\
(N=1030)\end{array}$ & 3.59 & 0.53 & 3.61 & 0.98 & 4.68 & 0.65 & 23.5 & 32.6 & 14.7 \\
\hline $\begin{array}{l}\text { Minimal obstruction } \\
(\mathrm{N}=256)\end{array}$ & 3.20 & 0.44 & 2.28 & 0.43 & 4.78 & 0.67 & 30.9 & 42.2 & 20.7 \\
\hline $\begin{array}{l}\text { Moderate obstruction } \\
(\mathrm{N}=111)\end{array}$ & 2.90 & 0.30 & 1.74 & 0.36 & 4.55 & 0.57 & 35.1 & 41.1 & 21.6 \\
\hline $\begin{array}{l}\text { Marked obstruction } \\
(\mathrm{N}=211)\end{array}$ & 2.40 & 0.37 & 1.26 & 0.42 & 4.31 & 0.55 & 48.3 & 52.6 & 36.0 \\
\hline $\begin{array}{l}\text { Marked obstruction } \\
\text { with restriction } \\
(\mathrm{N}=191)\end{array}$ & 1.92 & 0.53 & 1.08 & 0.46 & 3.48 & 0.48 & 60.7 & 60.0 & 44.5 \\
\hline $\begin{array}{l}\text { Restriction } \\
(\mathrm{N}=187)\end{array}$ & 2.80 & 0.35 & 2.79 & 0.79 & 3.64 & 0.46 & 44.9 & 50.0 & 26.7 \\
\hline
\end{tabular}

Table 3. Cumulative dust exposure, occurrence of silicosis, certification being sought or awarded and mortality from chronic obstructive lung disease and ischemic heart disease for the lung function profile groups, miners only.

\begin{tabular}{|c|c|c|c|c|c|c|c|}
\hline \multirow{2}{*}{$\begin{array}{l}\text { Lung function } \\
\text { profile group }\end{array}$} & \multicolumn{2}{|c|}{$\begin{array}{c}\text { Cumulative dust } \\
\text { exposure } \\
\text { (particle-years/1000) }\end{array}$} & \multirow{2}{*}{$\begin{array}{l}\text { Silicosis } \\
\quad(\%)\end{array}$} & \multicolumn{2}{|c|}{ Certification } & \multicolumn{2}{|c|}{$\begin{array}{c}\text { Mortality from } \\
\text { respiratory or } \\
\text { cardiovascular disease }\end{array}$} \\
\hline & Mean & $\mathrm{SD}$ & & $\begin{array}{l}\text { Benefits } \\
\text { being } \\
\text { sought } \\
(\%)\end{array}$ & $\begin{array}{c}\text { Benefits } \\
\text { awarded } \\
(\%)\end{array}$ & $\begin{array}{c}\text { Chronic } \\
\text { obstructive } \\
\text { lung disease } \\
(\%)\end{array}$ & $\begin{array}{c}\text { Ischemic } \\
\text { heart } \\
\text { disease } \\
(\%)\end{array}$ \\
\hline $\begin{array}{l}\text { Normal } \\
\text { (reference group) } \\
(N=1030)\end{array}$ & 28.2 & 12.1 & 4.6 & 12.9 & 11.1 & 0.3 & 14.2 \\
\hline $\begin{array}{l}\text { Minimal obstruction } \\
(N=256)\end{array}$ & 29.7 & 12.2 & 6.6 & 17.2 & 16.8 & 2.3 & 10.9 \\
\hline $\begin{array}{l}\text { Moderate obstruction } \\
(N=111)\end{array}$ & 31.5 & 13.0 & 18.0 & 17.1 & 24.3 & 3.6 & 12.6 \\
\hline $\begin{array}{l}\text { Marked obstruction } \\
(N=211)\end{array}$ & 30.6 & 11.4 & 8.1 & 22.3 & 29.4 & 7.1 & 21.3 \\
\hline $\begin{array}{l}\text { Marked obstruction } \\
\text { with restriction } \\
(N=191)\end{array}$ & 30.7 & 11.1 & 8.4 & 35.6 & 43.5 & 12.6 & 20.9 \\
\hline $\begin{array}{l}\text { Restriction } \\
(N=187)\end{array}$ & 30.5 & 11.9 & 7.0 & 21.4 & 23.5 & 0 & 27.3 \\
\hline
\end{tabular}

smokers. It can be seen that, for most of the profile groups, the nonsmokers did not display an increasing trend with an increase in dust exposure, while the exsmokers and current smokers did, and the trend increased with the degree of obstructive impairment.

Figure 2 shows the observed odds ratios and the odds ratios predicted by the additive and multiplicative models for each obstructive impairment. The odds ratios were plotted according to the smoking status and levels of dust particle-years/10 000. The predicted odds ratios for the two marked obstructive profiles were estimated from the additive model which included the interaction term. The multiplicative model did not include the interaction term as it was not found to be significant.

Table 5 shows the results of the analysis with the additive model (equation 1), fitted to the data for the marked-obstruction profiles in table 4, individually and combined. The results for the analysis from which the benefit examinations $(\mathrm{N}=248)$ were excluded are also shown. Table 5 shows the regression estimates, the associated chi-square test of significance, the goodness-of-fit test $\left(-2 \log L_{\mathrm{a}}\right)$, and the likelihood ratio test $\left(\mathrm{X}_{\mathrm{LR}}{ }^{2}\right)$ of the null hypothesis of no interaction for the additive model. The goodness-of-fit test $\left(-2 \log \mathrm{L}_{\mathrm{m}}\right)$ is presented for the multiplicative model fitted without an interaction term. Because of the narrow range, age was not a significant predictor for any impairment category. The regression coefficients estimated excess relative risk attributable to each exposure that was above the base-line risk, which was set at unity. Thus, for example, the estimated odds ratio for the marked obstruction with restriction impairment for the current smoker with a value of 5 for 
Table 4. Number of subjects according to their lung function profile and the observed odds ratios (OR), according to smoking habits and dust exposure.

\begin{tabular}{|c|c|c|c|c|c|c|c|c|c|c|c|}
\hline \multirow{3}{*}{$\begin{array}{l}\text { Dust exposure } \\
\text { (particle years/ } \\
10000 \text { ) }\end{array}$} & \multicolumn{11}{|c|}{ Profile group } \\
\hline & \multirow{2}{*}{$\begin{array}{l}\text { Normal } \\
\text { reference } \\
\text { group } \\
\text { (N) }\end{array}$} & \multicolumn{2}{|c|}{$\begin{array}{c}\text { Minimal } \\
\text { obstruction }\end{array}$} & \multicolumn{2}{|c|}{$\begin{array}{l}\text { Moderate } \\
\text { obstruction }\end{array}$} & \multicolumn{2}{|c|}{$\begin{array}{c}\text { Marked } \\
\text { obstruction }\end{array}$} & \multicolumn{2}{|c|}{$\begin{array}{c}\text { Marked } \\
\text { obstruction } \\
\text { + restriction }\end{array}$} & \multicolumn{2}{|c|}{ Restriction } \\
\hline & & $N$ & OR & $N$ & OR & $\mathrm{N}$ & OR & $N$ & OR & $N$ & OR \\
\hline \multicolumn{12}{|l|}{ Nonsmokers } \\
\hline $\begin{array}{r}0 \\
1.2 \\
2.0 \\
3.0 \\
4.0 \\
5.2\end{array}$ & $\begin{array}{l}56 \\
24 \\
54 \\
47 \\
30 \\
22\end{array}$ & $\begin{array}{l}6 \\
4 \\
6 \\
6 \\
4 \\
2\end{array}$ & $\begin{array}{l}1.0 \\
0.7 \\
0.8 \\
0.8 \\
0.6\end{array}$ & $\begin{array}{c}1 \\
-1 \\
2 \\
1 \\
1\end{array}$ & $\begin{array}{l}1.0^{\mathrm{a}} \\
0.5 \\
2.6 \\
2.4 \\
3.3\end{array}$ & $\begin{array}{r}2 \\
1 \\
2 \\
7 \\
1 \\
-\end{array}$ & $\begin{array}{l}1.0^{\mathrm{a}} \\
0.8 \\
2.6 \\
0.8 \\
0.4\end{array}$ & $\begin{array}{r}1 \\
-1 \\
1 \\
-\end{array}$ & $\begin{array}{l}1.0^{\mathrm{a}} \\
1.4 \\
1.6 \\
0.8 \\
1.1\end{array}$ & $\begin{array}{r}- \\
2 \\
5 \\
3 \\
1 \\
2\end{array}$ & $\begin{array}{l}1.0 \\
1.1 \\
0.8 \\
0.4 \\
1.1\end{array}$ \\
\hline \multicolumn{12}{|l|}{ Ex-smokers } \\
\hline $\begin{array}{r}0 \\
1.2 \\
2.0 \\
3.0 \\
4.0 \\
5.2\end{array}$ & $\begin{array}{l}67 \\
41 \\
83 \\
58 \\
42 \\
24\end{array}$ & $\begin{array}{r}13 \\
7 \\
14 \\
11 \\
16 \\
9\end{array}$ & $\begin{array}{l}1.0 \\
1.0 \\
1.1 \\
2.3 \\
2.3\end{array}$ & $\begin{array}{l}8 \\
2 \\
7 \\
6 \\
4 \\
5\end{array}$ & $\begin{array}{r}. \\
3.0 \\
4.4 \\
5.4 \\
5.2 \\
11.0\end{array}$ & $\begin{array}{l}7 \\
3 \\
5 \\
6 \\
5 \\
0\end{array}$ & $\begin{array}{l}. \\
1.4 \\
1.1 \\
1.8 \\
2.1 \\
0.3\end{array}$ & $\begin{array}{l}2 \\
2 \\
4 \\
4 \\
5 \\
3\end{array}$ & $\begin{array}{l}\cdot .0 \\
2.6 \\
3.8 \\
6.3 \\
7.0\end{array}$ & $\begin{array}{l}3 \\
2 \\
4 \\
8 \\
6 \\
5\end{array}$ & $\begin{array}{c}. \\
0.6 \\
0.6 \\
1.7 \\
1.7 \\
2.5\end{array}$ \\
\hline \multicolumn{12}{|l|}{ Current smokers } \\
\hline $\begin{array}{r}0 \\
1.2 \\
2.0 \\
3.0 \\
4.0 \\
5.2\end{array}$ & $\begin{array}{r}142 \\
62 \\
194 \\
188 \\
104 \\
57\end{array}$ & $\begin{array}{l}39 \\
16 \\
52 \\
56 \\
36 \\
17\end{array}$ & $\begin{array}{c}1.6 \\
1.6 \\
1.8 \\
2.1 \\
1.8\end{array}$ & $\begin{array}{r}29 \\
9 \\
21 \\
24 \\
18 \\
11\end{array}$ & $\begin{array}{c}. \\
7.5 \\
5.4 \\
6.4 \\
8.7 \\
9.8\end{array}$ & $\begin{array}{l}46 \\
10 \\
54 \\
54 \\
41 \\
22\end{array}$ & $\begin{array}{l}. \\
2.7 \\
4.6 \\
4.7 \\
6.5 \\
6.4\end{array}$ & $\begin{array}{r}26 \\
9 \\
52 \\
46 \\
50 \\
14\end{array}$ & $\begin{array}{r}7.5 \\
13.2 \\
12.1 \\
23.7 \\
12.4\end{array}$ & $\begin{array}{r}17 \\
9 \\
45 \\
56 \\
22 \\
17\end{array}$ & $\begin{array}{c}1.7 \\
2.8 \\
3.6 \\
2.5 \\
3.6\end{array}$ \\
\hline $\begin{array}{l}\text { Total } \\
\text { Miners }\end{array}$ & $\begin{array}{l}1295 \\
1030\end{array}$ & $\begin{array}{l}314 \\
256\end{array}$ & . & $\begin{array}{l}149 \\
111\end{array}$ & . & $\begin{array}{l}266 \\
211\end{array}$ & . & $\begin{array}{l}220 \\
191\end{array}$ & . & $\begin{array}{l}207 \\
187\end{array}$ & $i$ \\
\hline
\end{tabular}

a A value of 0.5 was added to each cell frequency.

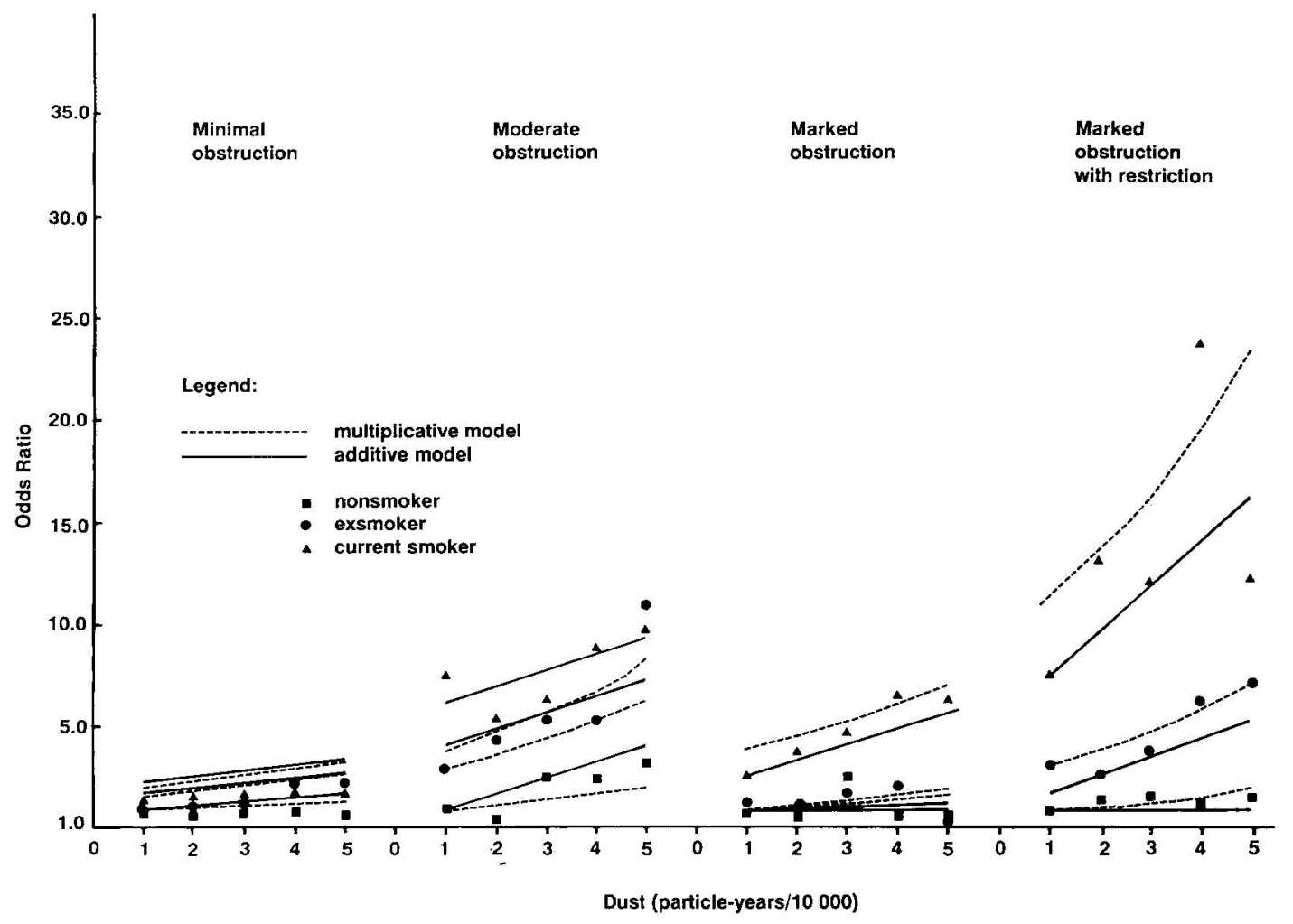

Figure 2. Observed and predicted odds ratios for individual lung function profiles, plotted against dust particle-years, according to smoking habits. 
Table 5. Results of the additive model, equation 1, fitted with indicator smoking variables and the categorized dust variable to the marked obstructive profiles.

\begin{tabular}{|c|c|c|c|c|c|c|c|c|c|c|c|c|}
\hline & \multicolumn{6}{|c|}{ Marked-obstructive profiles } & \multicolumn{6}{|c|}{ Marked-obstructive profiles combined } \\
\hline & \multicolumn{3}{|c|}{ Without restriction } & \multicolumn{3}{|c|}{ With restriction } & \multicolumn{3}{|c|}{ Benefits included } & \multicolumn{3}{|c|}{ Benefits excluded } \\
\hline & $\beta$ & SE & $x_{1}{ }^{2}$ & $\beta$ & SE & $x_{2}^{2}$ & $\beta$ & SE & $x_{1}^{2}$ & $\beta$ & SE & $x_{1}^{2}$ \\
\hline $\begin{array}{l}\text { Intercept } \\
\text { Dust } \\
\text { Ex-smoker } \\
\text { Gurrent smoker } \\
\text { Dust } \times \text { ex-smoker } \\
\text { Dust } \times \text { current smoker }\end{array}$ & $\begin{array}{r}-2.587 \\
-0.143 \\
0.107 \\
1.631 \\
0.163 \\
0.897\end{array}$ & $\begin{array}{l}0.289 \\
0.167 \\
0.649 \\
0.986 \\
0.247 \\
0.322\end{array}$ & $\begin{array}{r}80.1 \\
0.7 \\
0.1 \\
2.7 \\
0.4 \\
7.8\end{array}$ & $\begin{array}{r}-3.686 \\
-0.025 \\
0.810 \\
6.456 \\
0.878 \\
2.176\end{array}$ & $\begin{array}{l}0.461 \\
0.449 \\
1.320 \\
3.883 \\
0.596 \\
1.218\end{array}$ & $\begin{array}{r}63.9 \\
0.0 \\
0.3 \\
2.8 \\
2.2 \\
3.2\end{array}$ & $\begin{array}{r}-2.449 \\
-0.021 \\
0.337 \\
3.387 \\
0.309 \\
1.318\end{array}$ & $\begin{array}{l}0.266 \\
0.182 \\
0.616 \\
1.421 \\
0.234 \\
0.534\end{array}$ & $\begin{array}{l}84.8 \\
0.0 \\
0.3 \\
5.7^{\dagger} \\
1.7 \\
6.1^{\dagger}\end{array}$ & $\begin{array}{r}-2.552 \\
-0.082 \\
0.340 \\
3.125 \\
0.242 \\
1.265\end{array}$ & $\begin{array}{l}0.282 \\
0.183 \\
0.627 \\
1.472 \\
0.207 \\
0.298\end{array}$ & $\begin{array}{r}82.0 \\
0.2 \\
0.3 \\
4.5 \\
1.4 \\
18.0\end{array}$ \\
\hline $\begin{array}{l}-2 \log L_{a} \\
X^{2}(L R), d f=2 \\
-2 \log L_{m}\end{array}$ & \multicolumn{3}{|c|}{$\begin{array}{r}1099.2 \\
4.5 \\
1100.8\end{array}$} & \multicolumn{3}{|c|}{$\begin{array}{r}1007.2 \\
5.1 \\
1008.0\end{array}$} & \multicolumn{2}{|c|}{$\begin{array}{c}1594.8 \\
7.3^{\dagger} \\
1596.7\end{array}$} & \multicolumn{4}{|c|}{$\begin{array}{r}1239.9 \\
5.4 \\
1241.1\end{array}$} \\
\hline
\end{tabular}

a $-2 \log \mathrm{L}_{\mathrm{a}}=-2 \log$ likelihood, from additive model.

b $-2 \log \mathrm{L}_{m}=-2 \log$ likelihood, from multiplicative model

$+P<0.025$.

Table 6. Summary table of the log likelihood ratio tests for no interaction.

\begin{tabular}{lccc}
\hline \multirow{2}{*}{$\begin{array}{l}\text { Lung } \\
\text { function } \\
\text { profile }\end{array}$} & \multicolumn{3}{c}{ Additive model } \\
\cline { 2 - 4 } & $\begin{array}{r}1^{\mathrm{a}} \\
\left(\mathrm{X}_{2}{ }^{2}\right)\end{array}$ & $\begin{array}{c}2^{\mathrm{b}} \\
\left(\mathrm{X}_{1}{ }^{2}\right)\end{array}$ & $\begin{array}{c}3^{\mathrm{c}} \\
\left(\mathrm{X}_{1}{ }^{2}\right)\end{array}$ \\
\hline Obstruction & & & \\
$\quad$ Minimal & 3.3 & 0.1 & 0.0 \\
$\quad$ Moderate & 0.4 & 0.4 & 0.0 \\
$\quad$ Marked & 4.5 & $6.3^{\dagger}$ & $5.4^{\dagger}$ \\
$\quad$ Marked + restriction & 5.1 & $8.4^{\dagger}$ & $7.1^{\dagger}$ \\
All marked & $7.3^{\dagger}$ & $12.8^{\star \star \star}$ & $9.7^{\star \star}$ \\
All marked & 5.3 & $9.3^{\star \star}$ & $6.4^{\dagger}$ \\
Restriction & 3.6 & $4.0^{d}$ & $1.4^{-1}$ \\
\hline
\end{tabular}

a Model 1 used GOLDPYC, SMK1, SMK2 (likelihood ratio test with two degrees of freedom). (See the text for an explanation of the variables.)

b Model 2 used GOLDPY, SMOKEPY (likelihood ratio test with one degree of freedom). (See the text for an explanation of the variables.)

c Model 3 used GOLDPYC, SMOKEC (log likelihood test with one degree of freedom). (See the text for an explanation of the variables.)

d Marked obstruction without benefits.

$+\mathrm{P}<0.025,{ }^{* *} P<0.01, \cdots * P<0.001$

particle-years $/ 10000$ was calculated as $1-0.025$. $(5-1)+6.456+2.176 \cdot(5-1)=16.1$, and the observed value given in table 4 was 12.4. (See table 5 for the coefficients.) The interaction effect was found to be significant at the probability level of 0.05 for the combined marked-obstruction groups. As the interaction terms for the individual marked-obstruction groups were found to be significant for the other variable types, it is likely that adding the 0.5 value to the cell frequencies and combining the current smokers into one category decreased the interaction effect, which was significant at the probability level of 0.10 .

As the values of the miners with the lowest exposure were used as the base line, the value of one was subtracted from the dust exposure to obtain the value of 1.0 for the odds ratio in the lowest exposure category; this procedure should not have influenced the strength of the association.
Table 6 summarizes the results of the likelihood ratio tests of the absence of interaction effect for the obstructive and restrictive impairments for the categorized and continuous exposure variables as included in equations 1 and 2 . The interaction effect was not significant at the probability level of 0.05 for the minimal- and moderate-obstruction groups for any type of exposure variable. For the marked-obstruction groups (with and without restriction), the interaction effect was significant for the continuous and categorized variables. For the restrictive profile group the interaction effect between dust and smoking was not found to be significant.

Estimation of attributable risk. Table 7 shows the twoway.frequency distribution of all the marked-obstruction cases and of the reference subjects. The marginal odds ratios adjusted for each "other exposure" are shown. The odds ratios for the two-way cells show that the two highest smoking categories displayed the strongest dose-response trend with dust. The odds ratios in the two highest dust and smoking categories were approximately equal to the products of the marginal odds ratios and, therefore, indicated that the combined effect in these cells was almost multiplicative.

The etiologic fractions, estimated with equation 3 , were $48 \%$ [ $95 \%$ confidence interval $(95 \% \mathrm{CI})$ 40.2-55.2] for dust, $82 \%(95 \%$ CI 76.2-87.0) for smoking, and $90 \%$ ( $95 \%$ CI 86.6-92.6) for the combined effect of dust and smoking. The preventable fraction indicated that approximately $42 \%$ of the cases could have been prevented by the elimination of tobacco smoking, $8 \%$ by the elimination of dust exposure, and $40 \%$ by the elimination of either dust or smoking.

Table 8 summarizes the etiologic and preventable fractions. The value of the etiologic fraction is a reflection of the size of the marginal odds ratios for dust. It can be seen that the etiologic fractions for dust increase consistently as the degree of obstruction in- 
Table 7. Etiologic fractions for the marked obstructive profiles combined (marked obstruction + marked obstruction with restriction). ( $C=$ cases, $R=$ referents, $O R=$ odds ratio, $95 \% \mathrm{Cl}=95 \%$ confidence interval)

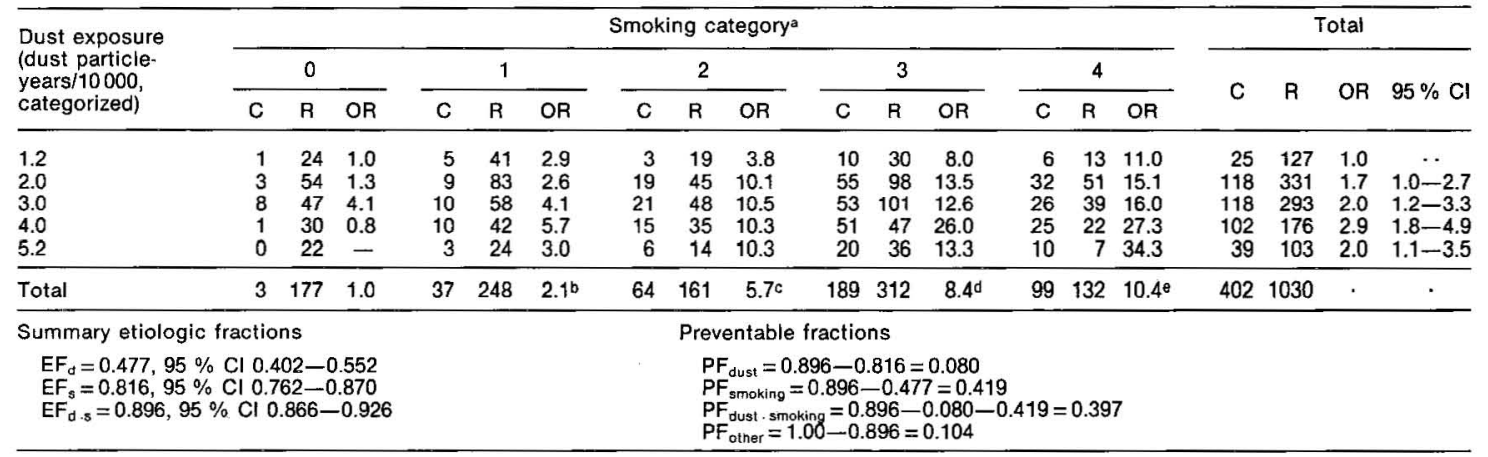

a Smoking categories: $0=$ never, $1=$ ex-smoker, $2=$ current smoker with $<20$ pack-years, $3=$ current smoker with $20-39$ pack-years, $4=$ current smoker with $\geq 40$ pack-years.

b $95 \% \mathrm{Cl}=1.1-4.1$.

c $95 \% \mathrm{Cl}=3.0-10.7$

d $95 \% \mathrm{Cl}=4.7-15.3$

e $95 \% \mathrm{Cl}=5.6-19.4$

Table 8. Summary of the etiologic and preventable fractions according to the degree of obstruction and restriction. (95\% $\mathrm{Cl}=$ confidence interval)

\begin{tabular}{|c|c|c|c|c|c|c|}
\hline & \multicolumn{6}{|c|}{ Risk factor } \\
\hline & \multicolumn{2}{|c|}{ Dust } & \multicolumn{2}{|c|}{ Smoking } & \multicolumn{2}{|c|}{ Dust and smoking } \\
\hline & $\%$ & $95 \% \mathrm{Cl}$ & $\%$ & $95 \% \mathrm{Cl}$ & $\%$ & $95 \% \mathrm{Cl}$ \\
\hline \multicolumn{7}{|l|}{ Etiologic fraction } \\
\hline $\begin{array}{l}\text { Minimal obstruction } \\
\text { Moderate obstruction } \\
\text { Marked obstruction } \\
\text { Marked obstruction }\end{array}$ & $\begin{array}{l}13.6 \\
20.0 \\
43.1\end{array}$ & $\begin{array}{r}2.3-24.9 \\
4.4-35.6 \\
32.7-53.5\end{array}$ & $\begin{array}{l}50.0 \\
79.8 \\
69.1\end{array}$ & $\begin{array}{l}41.8-58.2 \\
69.7-89.9 \\
61.1-77.1\end{array}$ & $\begin{array}{l}36.3 \\
83.9 \\
80.8\end{array}$ & $\begin{array}{l}30.9-41.7 \\
79.4-88.4 \\
76.4-85.2\end{array}$ \\
\hline $\begin{array}{l}\text { + restriction } \\
\text { All marked obstruction } \\
\text { All marked obstruction }\end{array}$ & $\begin{array}{l}51.7 \\
47.7 \\
42.2\end{array}$ & $\begin{array}{l}41.4-62.0 \\
40.2-55.2 \\
33.1-51.3\end{array}$ & $\begin{array}{l}94.1 \\
81.6 \\
80.1\end{array}$ & $\begin{array}{l}87.2-100 \\
76.2-87.0 \\
73.7-86.5\end{array}$ & $\begin{array}{l}90.6 \\
89.6 \\
86.3\end{array}$ & $\begin{array}{l}83.6-97.5 \\
86.6-92.6 \\
82.7-89.9\end{array}$ \\
\hline Restriction & 41.6 & $30.3-52.9$ & 59.8 & $50.9-68.7$ & 58.0 & $32.7-83.2$ \\
\hline \multicolumn{7}{|l|}{ Preventable fractions } \\
\hline $\begin{array}{l}\text { Minimal obstruction } \\
\text { Moderate obstruction } \\
\text { Marked obstruction } \\
\text { Marked obstruction }\end{array}$ & $\begin{array}{r}0 \\
4 \\
11\end{array}$ & $\begin{array}{l}\cdots \\
\cdots \\
\cdots\end{array}$ & $\begin{array}{l}23 \\
64 \\
38\end{array}$ & $\begin{array}{l}\cdots \\
\cdots \\
\cdots\end{array}$ & $\begin{array}{l}14 \\
16 \\
32\end{array}$ & $\begin{array}{l}\cdots \\
\cdots \\
\cdots\end{array}$ \\
\hline $\begin{array}{l}\text { + restriction } \\
\text { All marked obstruction }\end{array}$ & $\begin{array}{l}0 \\
8\end{array}$ & $\begin{array}{l}\cdots \\
\cdots\end{array}$ & $\begin{array}{l}30 \\
42\end{array}$ & $\begin{array}{l}\cdots \\
\cdots\end{array}$ & $\begin{array}{l}52 \\
40\end{array}$ & $\begin{array}{l}\cdots \\
\cdots\end{array}$ \\
\hline
\end{tabular}

a Benefit examinations excluded.

creases. For the two marked-obstruction groups the values were more than twice as high as that for the group with moderate obstruction, which had the highest dust exposure and highest proportion of men with silicosis. Thus the results indicate that heavy tobacco smoking potentiates the effect of dust on lung function impairment. The preventable fractions showed that, as the severity of the obstructive impairment increased, smoking on its own and the combined effects of smoking and dust became more important. The etiologic fractions for the marked-obstruction profiles from which those persons that came for a benefit examination were excluded were found to be only slightly lower than those obtained from all the data (table 8).

\section{Discussion}

The results of the present study indicate that for the lung function measurements $\left(\mathrm{FEV}_{1.0}, \mathrm{VC}\right.$, and $\mathrm{FEF}_{25-75}$ ) and the $\mathrm{FEV}_{1.0} / \mathrm{VC}$ ratio, the dose-response trends with dust were similar for the nonsmokers, exsmokers, and current smokers (figure 1). The interaction effect of dust and smoking was not statistically significant in the linear or logistic regression model. This result is consistent with the observations from studies on coal miners, as reviewed by Marine et al (23). Marine et al (23) stated that the results from the analysis of individual lung function tests, namely, $\mathrm{FEV}_{1.0}$, do not support the idea that cigarette smoking potentiates the effect of dust exposure or the chance of de- 
veloping symptoms of bronchitis or lung function decrements.

However, in our study, when the miners were grouped according to their profile of lung function impairment, a synergistic effect between dust and smoking became apparent. The miners with the markedobstruction profiles were found to have the highest tobacco consumption and the strongest dose-response trend with dust; yet they did not have the highest dust exposure or the highest proportion of men with silicosis (table 3). The dose-response trend with dust was found to be stronger for the marginal odds ratios adjusted for smoking (see the etiologic fractions in table 8), and for the current smokers (table 4 and figure 2), the latter of which was found to be mainly due to those whose tobacco consumption was over 20 packyears (table 7). Table 7 shows the marginal odds ratios for dust for the two marked-obstruction groups combined. For the moderate-obstruction group the corresponding odds ratios for dust were $0.9(95 \% \mathrm{CI}$ 0.4-1.9), $1.2(95 \%$ CI $0.6-2.5), 1.5(95 \% \mathrm{Cl} 0.7-$ 3.3 ), and 2.0 (95\% CI 0.9-4.5). Table 7 also shows that the odds ratios in the four highest exposure categories were approximately equal to the product of the marginal odds ratios, a finding indicating a multiplicative effect. Figure 2 shows that, with increasing obstruction, the number of impaired lung functions among the nonsmokers decreased and the doseresponse trend with dust became progressively steeper for the current smokers.

The log likelihood ratio tests obtained from fitting the additive relative risk model to different types of exposure variables confirmed that the joint effect of dust and tobacco smoking on the prevalence of marked obstruction was higher than would be expected from the additivity of individual effects (tables 5 and 6 ). No interaction term was significant for the multiplicative model.

The etiologic fractions, estimated for each impairment profile in comparison with that of the reference group, also displayed an increasing trend with the degree of obstruction (table 8). Reducing the respirable dust to which miners are exposed in South African gold mines to a nonharmful level would theoretically have prevented the occurrence of $48 \%$ of the impairments in the marked-obstruction profile groups $(\mathrm{N}=402)$. Eliminating tobacco smoking would prevent $82 \%$ of the impairments in these same groups and $94 \%(95 \%$ CI $87-100$ ) of the impairment in the group with marked-obstruction plus restriction $(\mathrm{N}=191)$, which had the highest mortality from chronic obstructive lung disease (table 3).

The results from the present study are consistent with those obtained from the mortality study of these miners. In the mortality study, the effect of dust and smoking on mortality from chronic obstructive lung disease was assessed (24). The results showed a similar pattern, namely, that the death rates from chronic obstructive lung disease occurred among tobacco smokers only and the dose-response trend with dust increased as the smoking level increased. The combined effect of the two exposures was close to being multiplicative. As the miners who died from chronic obstructive lung disease were mostly those who suffered from marked obstruction, the exposure patterns were similar.

The association between the restrictive profile and mortality from ischemic heart disease has been observed in several other studies (25), and in this study it may have been associated with obesity.

Possible biases in this study may be related to the selection of the nonmining referents, who were heavier smokers [the average equivalent pack-years being 27.1 (SE 1.0) and 24.3 (SE 0.4) $(\mathrm{P}<0.01)$ for the nonminers and miners, respectively] and had a higher prevalence of obstructive impairments. However, the nonsmoking nonminers also had a higher prevalence of obstructive impairments than the nonsmoking miners with the lowest dust level, and this circumstance could indicate either that the miners were fitter when selected originally or that a healthy worker effect was present. The use of the miners in the lowest dust category as the base-line group could have led to an underestimation of the effect of dust, but less so than if the nonminers had been used for this purpose.

A selection bias, whereby the fitter workers accumulate higher dust exposures, was probably involved also in this study and may have caused an underestimation of the effect of dust and of the synergistic effect. When we examined the cumulative particle-years by the decades (ie, the 1940s, 1950s, 1960s, and 1970s), the normal and minimal-obstruction profile groups consistently had the lowest exposure, whereas the groups with marked obstruction (with and without restriction) or restriction decreased their exposure mostly during the 1960 s in comparison with the exposure of the moderate-obstruction group. Furthermore, a negative association between tobacco consumption and dust exposure was observed among the miners. The mean pack-years, according to the categories of dust particleyears, were 27.1, 25.2, 25.2, 23.2, and 23.6. This finding indicates that the miners who smoked less were fitter to continue to work in dusty occupations. Zwi (26) has also observed that gold miners doing the heaviest work with the greatest dust exposure had the best lung function, and more recently this observation was confirmed for black gold miners (27). This effect may have been responsible for the change in the doseresponse trend in the highest dust-exposure category, as shown in figure 1.

The miners whose original spirograms were rejected because of inconsistencies, and consequently their lung function data were not recorded in the computer file, were compared with the miners who were included in the study. They were found to have a higher exposure to dust (in particle-years) up to $1970(\mathrm{P}=0.001)$, but the difference in cigarette equivalent pack-years was not statistically significant. They had a higher mortality 
from all causes, 55 versus $46 \%(\mathrm{P}<0.0001)$, and from chronic obstructive lung disease, 8 versus $3 \%$ $(\mathrm{P}<0.0001)$. Thus the exclusion of these men from the original study and from this analysis has very likely resulted in an underestimation of the effect of dust.

The miners selected for this study could have come to the Medical Bureau for Occupational Diseases for a regular annual (so-called periodic) examination or a specialized (so-called benefit) examination. A miner may attend a benefit examination one year and a periodical examination the next. By the age of 45 years many miners have already accumulated the service required for compensation and thus request the benefit examination to establish whether they qualify for compensation. Table 9 shows the miners categorized according to the reason for attending the medical examination. The mean dust exposures, accumulated according to the individual decades, were higher and the lung function measurements lower for the benefit examinations than for the periodic examinations. No important differences in age, body weight or height, body mass index, or tobacco consumption were observed between the four groups. The possibility that the men who came for their benefit examination could have biased the results of this study was considered. The analysis presented in tables 5 and 6 were repeated, and those who had attended the benefit examinations were excluded. The pattern of the dose-response trends and the regression results were very similar to those reported. Table 8 shows that the etiologic fractions calculated for all marked obstruction changed only slightly. Generally, the overall pattern was the same as that obtained from all the data.

It can bee seen that the disability certification (table 3), which leads to financial compensation, was related to the amount of tobacco consumption (table 1). The moderate-obstruction group, which had higher dust exposure, a higher rate of silicosis, and lower tobacco consumption in comparison with the two marked-obstruction groups had a lower rate of certifi- cation for chronic obstructive lung disease or pneumoconiosis than the latter two groups. Thus it appears that the heavily smoking miners had an advantage for compensation over the more heavily dust-exposed miners who smoked less.

There are several possible reasons for the different results obtained from the analysis of the individual tests and from the analysis of the profile groups with respect to the interaction effect. First, categorizing the men on the basis of their spirogram performance may have helped to eliminate misclassification errors for the disability. Second, obstructive impairment is a function of $\mathrm{FEV}_{1.0}$ and $\mathrm{VC}(28)$, and, if exposure to dust causes parallel reduction in the $\mathrm{FEV}_{1.0}$ and $\mathrm{VC}$ (29), then the $\mathrm{FEV}_{1,0} / \mathrm{VC}$ ratio, often used as a measure of obstruction, may not change with increasing dust level. In our study the parallel reduction in airflow and lung volume was considered. The observed midexpiratory flow time, used in the grouping, was independent of the predicted values. Third, the impaired miners were compared with the miners who had "normal" lung function tests, and in relation to these miners the synergistic effect of dust and smoking became apparent. Finally, grouping the men according to their lung function profiles produced more homogeneous groups with respect to exposure pattern.

It has been shown that the logistic model, often used for the analysis of dichotomous outcome variables, assumes multiplicativity of relative risks and thus may not detect synergistic effects that are important from the point of view of public health (14). It has been proposed that, when the multiplicative model fits the data substantially better than the additive model without an interaction term, then a synergistic effect of public health importance can be assumed (15). The results from this study support the proposition. Figure 2 and the log likelihoods in table 5 show that the additive model with interaction and the multiplicative model without interaction fit the data equally well. It has been shown that the parameter error estimates obtained

Table 9. Comparison of miners with different reasons for attending the annual medical examination.

\begin{tabular}{|c|c|c|c|c|c|c|c|c|}
\hline & \multicolumn{4}{|c|}{ Periodic examination } & \multicolumn{4}{|c|}{ Benefit examination } \\
\hline & \multicolumn{2}{|c|}{$\begin{array}{l}\text { Active miner } \\
(N=1536)\end{array}$} & \multicolumn{2}{|c|}{$\begin{array}{l}\text { Inactive miner } \\
\quad(\mathrm{N}=93)\end{array}$} & \multicolumn{2}{|c|}{$\begin{array}{l}\text { Active miner } \\
(N=260)\end{array}$} & \multicolumn{2}{|c|}{$\begin{array}{l}\text { Inactive miner } \\
(\mathrm{N}=92)\end{array}$} \\
\hline & Mean & SD & Mean & SD & Mean & SD & Mean & SD \\
\hline \multicolumn{9}{|c|}{$\begin{array}{l}\text { Cumulative dust exposure } \\
\text { (particle-years/1000) as } \\
\text { of a particular year }\end{array}$} \\
\hline $\begin{array}{l}1950 \\
1960 \\
1970\end{array}$ & $\begin{array}{r}9.0 \\
19.4 \\
28.8\end{array}$ & $\begin{array}{r}5.1 \\
8.3 \\
12.1\end{array}$ & $\begin{array}{l}10.0 \\
20.0 \\
25.5\end{array}$ & $\begin{array}{l}4.8 \\
7.2 \\
8.9\end{array}$ & $\begin{array}{l}11.2 \\
23.6 \\
34.3\end{array}$ & $\begin{array}{r}4.9 \\
8.1 \\
11.4\end{array}$ & $\begin{array}{l}10.8 \\
21.8 \\
27.1\end{array}$ & $\begin{array}{r}4.8 \\
7.7 \\
10.7\end{array}$ \\
\hline \multicolumn{9}{|c|}{$\begin{array}{l}\text { Lung function at the medical } \\
\text { examination }\end{array}$} \\
\hline $\begin{array}{l}\mathrm{FEV}_{1.0} \\
\text { VC } \\
\mathrm{FEF}_{25-75} \\
\mathrm{FEV}_{1.0} / \mathrm{VC}\end{array}$ & $\begin{array}{r}3.21 \\
4.49 \\
2.86 \\
71.3\end{array}$ & $\begin{array}{l}0.72 \\
0.76 \\
1.26 \\
9.5\end{array}$ & $\begin{array}{r}3.13 \\
4.37 \\
2.76 \\
71.7\end{array}$ & $\begin{array}{l}0.66 \\
0.71 \\
1.19 \\
9.3\end{array}$ & $\begin{array}{c}2.83 \\
4.16 \\
2.38 \\
67.5\end{array}$ & $\begin{array}{c}0.73 \\
0.68 \\
1.18 \\
12.7\end{array}$ & $\begin{array}{c}2.85 \\
4.32 \\
2.34 \\
64.8\end{array}$ & $\begin{array}{c}0.93 \\
0.88 \\
1.36 \\
14.8\end{array}$ \\
\hline
\end{tabular}

a $\mathrm{FEV}_{1.0}=$ forced expiratory volume on $1 \mathrm{~s}, \mathrm{VC}=$ vital capacity, $\mathrm{FEF}_{25-75}=$ forced midexpiratory flow. 
from the additive model are unreliable for inference purposes and that the log likelihood ratio statistic for the absence of effect can be used to test the hypotheses of additivity or multiplicativity of relative risks (30).

In conclusion, it can be said that this study supports the hypothesis that tobacco smoking potentiates the effect of dust exposure in underground gold mining and increases the chances of developing a severe obstructive impairment in lung function that leads to increased mortality from chronic obstructive lung disease.

\section{References}

1. Beadle DG, Bradley AA. The composition of airborne dust in South African gold mines. In: Shapiro HA, ed, Pneumoconiosis, proceedings of the international conference, Johannesburg 1969. Cape Town: Oxford University Press, 1970:462-6.

2. Sluis-Cremer GK, Walters LG, Sichel HS. Chronic bronchitis in miners and non-miners: an epidemiological survey of a community in the gold-mining area in the Transvaal. Br J Ind Med 1967;42:1-12.

3. Wiles FJ, Faure MH. Chronic obstructive lung disease in gold miners. In: Walton WH, ed. Inhaled particles IV. Oxford: Pergamon Press, 1977:727-35.

4. Becklake MR, Irwig L, Kielkowski D, Webster I, De Beer M, Landau S. The predictors of emphysema in South African gold miners. Am Rev Respir Dis 1987;135:1234- 41 .

5. Wright JL, Harrison N, Churg A. Quartz but not iron oxide cause airflow obstruction, emphysema, and small airway lesions in the rat. Am Rev Respir Dis 1988; 137:49.

6. Churg A, Hobson J, Wright J. Functional and morphological comparison of silica- and elastase induced airflow obstruction. Exp Lung Res 1989;15:813-22.

7. Holman CDJ, Psaila-Savona P, Roberts M, McNulty JC. Determinants of chronic bronchitis and lung dysfunction in Western Australian gold miners. $\mathrm{Br} \mathrm{J}$ Ind Med 1987;44:810-8.

8. Burns DM, Froines JR, Murray EJ. Biological interactions between smoking and occupational exposures. Am $J$ Ind Med 1988;13:169-79.

9. Harber P, Tashkin DP, Lew M, Simmons M. Physiological categorization of asbestos-exposed workers. Chest 1987;92:494-9.

10. Beadle DG. The relationship between the amount of dust breathed and the development of radiological signs of silicosis: an epidemiological study of South African gold miners. In: Walton WH, ed, Inhaled particles III. Oxford: Pergamon Press, 1971:953-66.

11. Crapo RO, Morris AH, Gardner RM. Reference spirometric values using techniques and equipment that meet ATS recommendations. Am Rev Respir Dis 1981;123: $659-64$
12. Barlow WE. General relative risk models in stratified epidemiological studies. Appl Stat 1985;34:246-57.

13. Breslow NE, Storer BE. General relative risk functions for case-control studies. Am J Epidemiol 1985;122: 149-62.

14. Rothman KJ. Synergy and antagonism in cause-effect relationships. Am J Epidemiol 1974;99:385-8.

15. Blot WJ, Day NE. Synergism and interaction: are they equivalent? Am J Epidemiol 1979;110:99-100.

16. Thomas DC. Program "Risk" user's manual (1980). Montreal: McGill University, 1980.

17. James F, Roos M. "MINUIT"-A system for function minimization and analysis of the parameter errors and correlations. Comput Phys Commun 1975;10:343-67.

18. SAS Inc. SAS User's Guide. Cary, NC: SAS Inc, 1982; $1-584$.

19. Miettinen OS. Proportion of disease caused or prevented by a given exposure, trait or intervention. Am J Epidemiol 1974;99:325-31.

20. Bruzzi P, Green SB, Byar DP, Brinton LA, Schairer C. Estimating the population attributable risk for multiple risk factors using case-control data. Am J Epidemiol 1985;122:904-14.

21. Kjuus $H$, Langard $S$, Skjaerven $R$. A case-control study of lung cancer, occupational exposures and smoking: III. etiological fraction of occupational exposures. Scand J Work Environ Health 1986;12:210-15.

22. Denman DW, Schlesselman JJ. Interval estimation of the attributable risk for multiple exposure levels in casecontrol studies. Biometrics 1983;39:185-92.

23. Marine WM, Gurr D, Jacobsen M. Clinically important respiratory effects of dust exposure and smoking in British coal miners. Am Rev Respir Dis 1988;137: $106-12$.

24. Hnizdo E. Combined effect of silica dust and tobacco smoking on mortality from chronic obstructive lung disease in gold miners. Br $\mathrm{J}$ Ind Med (in press).

25. Kannel WB, Hubert $\mathbf{H}$, Lew EA. Vital capacity as a predictor of cardiovascular disease: the Framingham study. Am Heart J 1983;105:311-15.

26. Zwi S. Lung function of Witwatersrand gold miners. In: Orenstein AJ, ed. Praceedings of the pneumoconiosis conference, Johannesburg 1959. London: Churchill, 1960:522-30.

27. Cowie RL. Silicosis, pulmonary dysfunction and respiratory symptoms in South African gold miners [Doctoral dissertation]. Montreal: McGill University, 1987.

28. Morgan WKC. Update on lung disease in coal miners [Correspondence]. Br J Ind Med 1987;44:716-20.

29. Soutar CA, Hurley JF. Relation between dust exposure and lung function in miners and ex-miners. $\mathrm{Br} \mathrm{J}$ Ind Med 1986;43:307-20.

30. Moolgavkar SH, Venzon DJ. General relative risk regression models for epidemiological studies. Am J Epidemiol 1987;126:949--61.

Received for publication: 8 December 1989 